\title{
Effect of cardamom powder and rosemary extract on textural, sensory, microbiological and colour properties of pinni during storage
}

\author{
Ravinder Singh $^{1}$, Kaushik Khamrui ${ }^{2}$ and Writhdhama Prasad ${ }^{2}$
}

Received: 14 February 2020 / Accepted: 22 July 2020 / Published online: 27 October 2020

(C) Indian Dairy Association (India) 2020

\begin{abstract}
Pinni is an immensely popular milk cereal based composite sweet having dark brown colour with granular texture. The shelf life of pinni was studied by using natural preservatives i.e., cardamom powder and rosemary extract. Two packaging techniques viz., cardboard boxes and polystyrene tray were compared for sensory, textural, microbiological and colour quality of pinni during storage for 21 days and 28 days respectively at $30 \pm 1^{\circ} \mathrm{C}$. The extent of loss of most sensory attributes was rapid in control samples packed in both packaging materials as compared to cardamom and rosemary extract added pinni samples. Based on the results obtained in the study it was concluded that pinni could be best preserved up to 28 days at room temperature $\left(30 \pm 1^{\circ} \mathrm{C}\right)$ without appreciable quality loss and should be packed in polystyrene trays with rosemary extract and have shelf life 14 days more than control sample.
\end{abstract}

Keywords: Cardamom, Pinni, Rosemary extract, Shelf-life

\section{Introduction}

Conversion of raw milk into a wide variety of milk products has been practiced in our country since time immemorial. Amongst various categories of Indian milk based sweets available, heat desiccated variants presents a pleasing and healthful variety of

${ }^{1}$ Department of Food Processing Technology, Sri Guru Granth Sahib World University, Fathehgarh Sahib, Punjab 140406, India

${ }^{2}$ Dairy Technology Division, ICAR-National Dairy Research Institute, Karnal - 132 001, Haryana, India

Kaushik Khamrui ( $\square)$

Dairy Technology Division, ICAR-National Dairy Research Institute, Karnal - 132 001, Haryana, India

Email:kkhamrui@gmail.com products compared to others because whole milk is used for producing those products. India has the largest repository of such products and out of them pinni is an immensely popular traditional milk-cereal based sweet of Northern states of India mainly Punjab, Haryana and Delhi. The product is a rich source of nutrients derived from milk solids as well as goodness of wheat or gram flour, nuts, dry fruits etc. It is also a concentrated source of fat, protein, minerals and energy. Considering its high nutritive value, traditionally pinni is considered as an ideal food for young ones in their grow-ing stage, pregnant and lactating women (Talwar and Brar, 2015).

Milk products undergo changes during storage, showing adverse effects on quality, ranging from minor sensory defects to complete spoilage (Kotsianis et al. 2002). Several physico-chemical and microbiological changes may take place making them unfit for human consumption. Food products, especially dairy products prepared under strict hygienic conditions are likely to be spoiled quickly if they are not stored properly. Like other milk products pinni also has limited shelf life about 10 days packed in high density polythene pouches, (Saxena et al. 1996). Because of its high fat content and non-acidic nature, spoilage in pinni is mostly caused by growth of surface yeasts and moulds and manifests as fermentative and acidic as well as rancid odour also observed during storage. This is a recurrent problem in humid and warm atmospheric conditions that are prevalent in tropics.

With the increasing demand of cheap, non-toxic and natural food preservatives globally, it was possible to extend the shelf life of many perishable and non-perishable foods by using cardamom and rosemary extract (Jessica et al. 2015). However, commercial application of cardamom and rosemary extract for Indian milk products is still at a nascent stage. Several studies have been reported to extend the shelf life of different food products using cardamom; Palit and Pal (2005) observed that vacuum packaging and addition of cardamom and potassium sorbate, each at the rate of $0.1 \%$ of $k h o a(\mathrm{w} / \mathrm{w})$ increased the shelf life of burfi upto 60 days at $30 \pm 1$ ÚC. Prasad et al. (2017a) reported that the flavour score of cardamom added burfi was not significantly $(\mathrm{p}>0.05)$ different from that of control burfi. Cardamom incorporated yoghurt (Vijaylakhshmi et al. 2014) and rosemary extract (RME) enriched ghee showed significantly higher anti-oxidant activity. 
The presence of antioxidants reduces oxidative changes of fats and enhances shelf-life. Quality and properties of packaging material affects shelf life of a food product. Several studies have been reported on increased shelf-life of traditional dairy products using spices and herbs (Londhe et al. 2012 and Ghayal et al. 2015). Sweets like kalakand, milk-cake and other sweets have been packaged in paper cartons or duplex board boxes as reported by Goyal and Rajoriha (1991) to enhance shelf life. The present study was conducted to study the effect of two natural preservatives i.e., cardamom powder and rosemary extract on physico-chemical, sensory and microbiological attributes of pinni packed in two different packaging materials viz., cardboard boxes and polystyrene trays.

\section{Materials and Methods}

\section{Raw materials}

Freshly pooled buffalo milk obtained from NDRI Karnal Cattle Yard, was standardized to $6.0 \%$ fat and $9.0 \%$ SNF. Food grade cane sugar (sucrose) and cardamom powder were obtained from the local market. Wheat flour of Aashirvad brand was procured from local market; it contained $11.8 \%$ protein, $1.7 \%$ fat and 75.1 $\%$ carbohydrate. Ghee prepared from buffalo milk was procured from the Experimental Dairy of the Institute and it contained $99.5 \%$ fat and $0.5 \%$ moisture. Free sample of rosemary extract was supplied by M/s Zakinl Biotech private limited (Chamrajnagar, Karnataka, India).

\section{Preparation of $\mathbf{k h o a}$}

Khoa samples were prepared from buffalo milk using the method of Bhatele (1983) with some modification such as open double jacketed stainless-steel kettle at a steam pressure of $2 \mathrm{~kg} / \mathrm{cm}^{2}$ instead of a karahi over a brisk non - smoky fire.

\section{Preparation and compositional analyses of pinni}

A batch of approximately $2 \mathrm{~kg}$ of pinni was prepared in triplicate for each experiment. Ghee (540 g) was taken in a heavy bottom pan then heated to $90^{\circ} \mathrm{C}$ and wheat flour $(682 \mathrm{~g})$ was added. Roasting of wheat flour was done at $90^{\circ} \mathrm{C}$ till typical roasted flavour and color was developed. The $k h o a(400 \mathrm{~g})$ was then added accompanied by continuous stirring to break the large lumps into small granules. Roasting was continued and sugar (360 g) was added and stirred to properly mix the ingredients. After this stage heating was discontinued and the mixture was allowed to cool to room temperature $\left(30^{\circ} \mathrm{C}\right)$. Cardamom powder was added @ $2.5 \%$ (of pinni) and rosemary extract $200 \mathrm{mg}$ and then using a hand operated cylindrical mould the product was moulded into $25 \mathrm{~g}$ cylinders each. The proximate composition of the pinni in terms of moisture (IS: SP: Part 18 XI, 1981), fat (IS, 1981), protein (Meneffee \& Overman, 1940), sucrose (IS: SP: Part 18 XI, 1981) and ash IS: SP:18 (Part XI, 1981) was estimated.

\section{Packaging of pinni}

Packaging materials for pinni i.e. cardboard boxes of $15 \times 12 \times 15$ $(\mathrm{L} \times \mathrm{B} \times \mathrm{H}) \mathrm{cm}$ were procured from the local market of Karnal, Haryana and Polystyrene (PS) trays (thickness: $1.50 \mathrm{~mm}$; WVTR: $1.96 \mathrm{~g} / \mathrm{m}^{2}-24 \mathrm{~h}$; OTR: $26 \mathrm{~mL} / \mathrm{m}^{2}-24 \mathrm{~h}$ ) were procured from M/s Elixir Technologies, Bangalore. Trays were sealed with PolyamidePolyethylene films.

\section{Sensory evaluation}

Sensory evaluation of fresh and stored samples of pinni was carried out in terms of flavor, body and texture and colour and appearance using a 9-point Hedonic scale. Seven members of semi-trained sensory evaluation panelists constituted from the faculty of Dairy Technology Division, National Dairy Research Institute, Karnal performed the sensory evaluation. Panel members carried out sensory evaluation in individual booths where an intact piece of pinni (tempered to 15ÚC) was presented with random three-digit codes in closed glass containers. Samples were served monadically with de-ionized water. Each panelist offered independent observation on randomized samples of pinni.

\section{Colour measurement}

Colour measurements were conducted as described by Nalwade et al. (2014) using Color Flex (Hunter Associates Laboratory, Inc., Reston VA, USA) colour measurement system equipped with dual beam xenon flash lamp and universal software. The instrument was calibrated prior to sample measurements with standard black, white and green tile as prescribed by the supplier. The results were represented by the Hunter $L^{*}, a^{*}, b^{*}$ notation.

\section{Texture Profile Analysis (TPA)}

Stable Micro System Texture Analyser, Model No: - TAXT2i; as described in Khamrui and Solanki (2010) fitted with a $25 \mathrm{~kg}$ load cell was used to measure the textural attributes of cylindrical samples of pinni measuring $15 \mathrm{~mm}$ height and $20 \mathrm{~mm}$ diameter. Samples tempered to $25^{\circ} \mathrm{C}$ were compressed to $70 \%$ of their initial height using an aluminium $75 \mathrm{~mm}$ diameter compression plate (P75), maximum force exerted by the sample, i.e., the peak of the force-time curve was measured as hardness $(\mathrm{N})$ and fracturability is a force at the first significant break at the TPA curve. The texture analyzer settings that were employed to determine the textural attributes were; program: return to start, load cell: $25 \mathrm{~kg}$, probe type: P-75 compression plate; pre-test, test, and post-test speed: $2 \mathrm{~mm} / \mathrm{s}$ trigger type: auto, trigger force: $5 \mathrm{~g}$, threshold: 50 $\mathrm{g}$, time: $2 \mathrm{~S}$ data acquisition rate: $250 \mathrm{pps}$. This measurement was performed in triplicate on the three random samples of a batch.

\section{Statistical analysis}

The data generated from present study was analyzed using ANOVA for determining difference in mean using SAS ver. 5.3 
(SAS Institute Inc., Cary, NC). Wherever, required in the study, the overall mean and standard error of the data was calculated.

\section{Results and Discussion}

The proximate composition of the pinni was found to be moisture $5.2 \% \pm 0.34$ fat $36.74 \% \pm 0.33$, protein $9.13 \% \pm 0.5$, sucrose $40.67 \%$ \pm 0.45 and ash $1 \% \pm 0.5$.

\section{Changes in sensory quality of pinni during storage}

The sensory scores showed a decreasing trend during storage in all samples of pinni irrespective of packaging techniques (Fig. 1). Significant $(p<0.05)$ effect of addition of cardamom and rosemary was noticed on flavour score of pinni in both the packaging materials at $30^{\circ} \mathrm{C}$. Maximum score was recorded in rosemary added and polystyrene tray packed samples since PS has better moisture and oxygen barrier properties. In present study pinni was criticized for lack of freshness at the end of storage period of 28 days. Similar observations with respect to flavour degradation were reported for doda burfi by Chawla et al. 2015b. During storage of pinni in cardboard boxes and polystyrene trays at $30 \pm 1$ ÚC significant $(\mathrm{p}<0.05)$ decrease in body and texture score was observed. (Fig. 1). The stored samples progressively became brittle and showed decrease in cohesiveness. Londhe et al. (2012) reported rapid reduction in body texture score for control samples of brown peda at 30ÚC as compared to vacuum packed samples which were acceptable upto 40 days. Decreasing trend in colour and appearance score was observed in case of control, cardamom and rosemary extract added pinni samples respectively (Fig. 1). Different treatments showed significant $(\mathrm{p}<0.05)$ effect on colour and appearance score of pinni in both the packaging materials at any particular storage interval. Probable reason for reduction in colour and appearance score could due to change in surface appearance of pinni caused by loss of moisture from surface and darkening of samples with progress of storage period. Decrease in colour scores was also observed during storage of brown peda by Londhe et al. (2012. During storage of pinni in cardboard boxes as well as in PS trays at $30 \pm 1{ }^{\circ} \mathrm{C}$ significant $(p<0.05)$ decrease in sweetness score was recorded except in rosemary added samples in both the packaging material. Addition of rosemary extract and cardamom had significant $(\mathrm{p}<0.05)$ effect on overall acceptability score of pinni samples packed in both the packaging materials. The reduction in overall acceptability score of pinni was possibly due to formation of stale flavour, and increased brittleness with storage. Controlled samples stored at $30^{\circ} \mathrm{C}$ were found to have mould growth after 14 days of storage in both packaging materials which resulted in reduced acceptability. However, cardamom added samples were found to have mould growth after 21 days of storage in both packaging materials and rosemary added pinni samples have shelf life 21 days in cardboard boxes and 28 days in PS trays that results indicated antioxidant effects of rosemary. Despite decreasing trend, the samples were found to score well over the minimum acceptable limit (i.e., a score of 7). The overall acceptability of doda burfi was reported to decrease and caused dark colour formation with storage (Chawla et al. 2015b). These results are in agreement with the finding of Prabha (2006) and Londhe (2006). These changes in sensory scores during storage are reflection of the predominant flavour reduction of pinni, with increased staleness as storage preceded, and followed by deteriorating colour and appearance and body and texture due to drying, dark colour formation and brittle texture development of the product.

\section{Textural changes of pinni during storage}

The changes in textural quality of pinni in terms of texture profile analysis (TPA) during storage packaged under different packaging conditions are given in Fig. 2. In the present study, a gradual increase in hardness in all pinni samples irrespective of the packaging material was observed, which could be attributed to the decrease in moisture content in the product (data not reported) This result was in accordance with the earlier findings of Saxena et al. (1996) who reported that increase in hardness of pinni with increase of storage period. While some worker likes Jha et al. (2014b), Gupta et al. (1990) and Suresh et al. (1994), found that increase of hardness of khoa correlates with the increase in the total solid content and that the moisture content of peda had direct relationship with hardness of the product.

Fracturability of fresh pinni decreased significantly $(\mathrm{p}<0.05)$ in both packaging materials. In general, as the moisture content increased (data not reported) fracturability of pinni indicating that the samples having higher moisture content was softer, hence broke on application of lower amount of force. Springiness refers to a food's ability to return to its original form after compression. It is the height that the sample recovers between the first and second compression. Cohesiveness is the ratio of area under the second bite curve before reversal of compression to that under the first bite curve. It is the measure of the extent to which the food structure is disrupted during the first compression (Bourne, 2002). Cohesiveness value of fresh pinni decreased nonsignificantly $(\mathrm{p}>0.05)$ in both packaging material (Fig. 2).

Gumminess is related to the primary parameters such as hardness and cohesiveness. Gumminess of freshly prepared pinni increased non-significantly $(p>0.05)$ at the end of storage period in both packaging materials. Gumminess of pinni showed a trend similar to one noticed for hardness and cohesiveness the former being a secondary parameter based on hardness. Gumminess of brown peda $(12.56 \mathrm{~N})$ increased to $20.51 \mathrm{~N}$ after 40 days in vacuum packaging (Londhe et al.2012). Chewiness refers to the energy required to masticate food into a state ready for swallowing and is the product of gumminess and springiness. Chewiness value of pinni increased significantly $(\mathrm{p}<0.05)$ in both packaging materials. Chewiness of fresh cow, buffalo and mixed milk rasogolla was reported to be $28.70,73.70$ and $34.50 \mathrm{~N}$ by Adhikari 


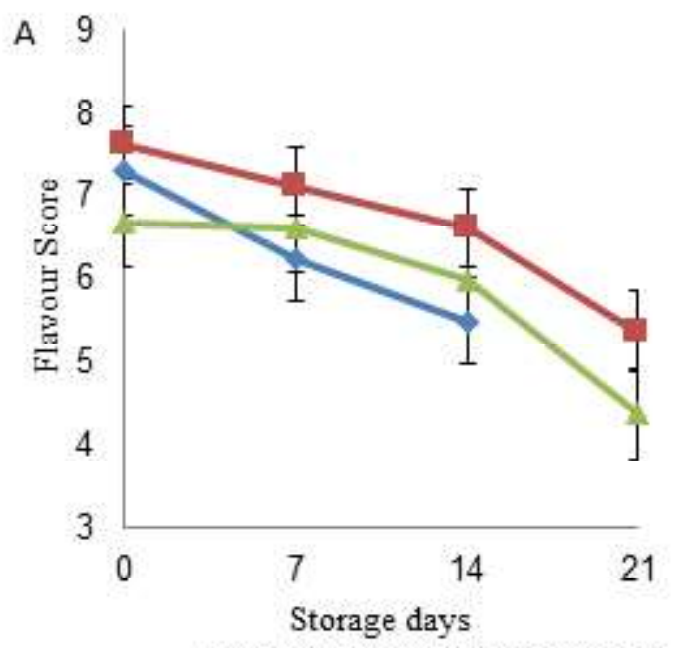

(a) Pinni packed in cardboard boxes

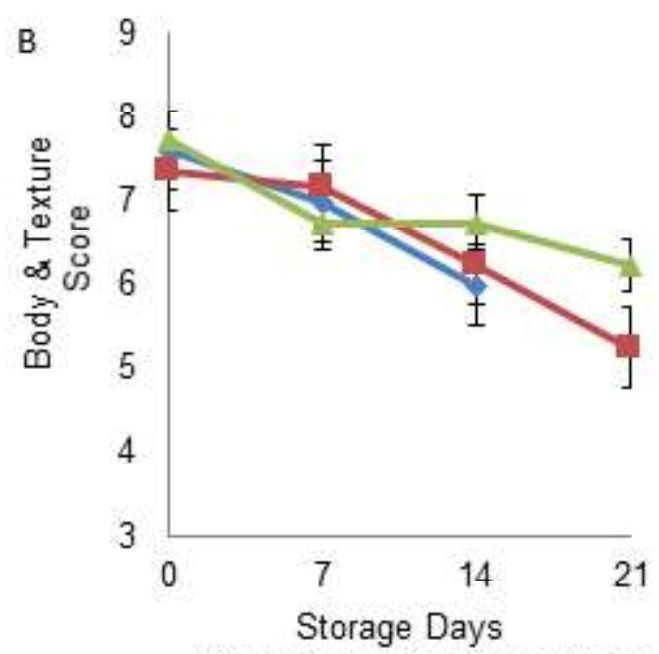

(a) Pinni packed in cardboard boxes

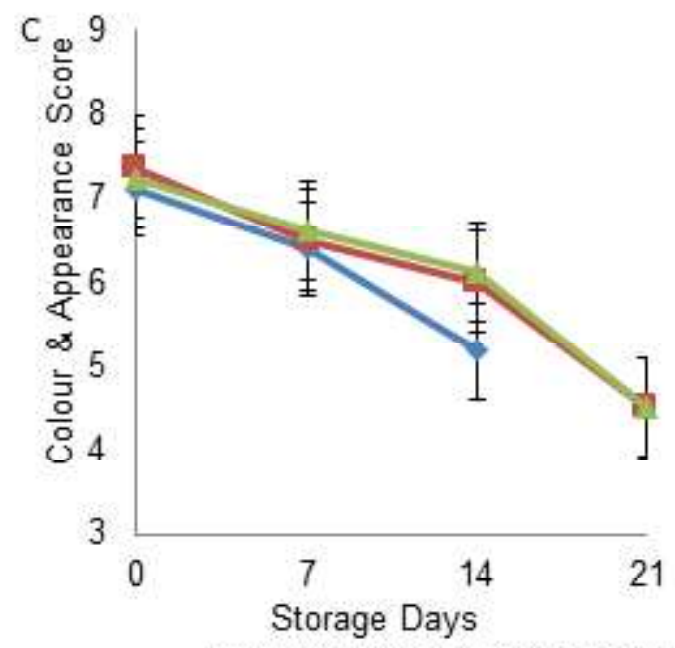

(a) Pinni packed in cardboard boxes

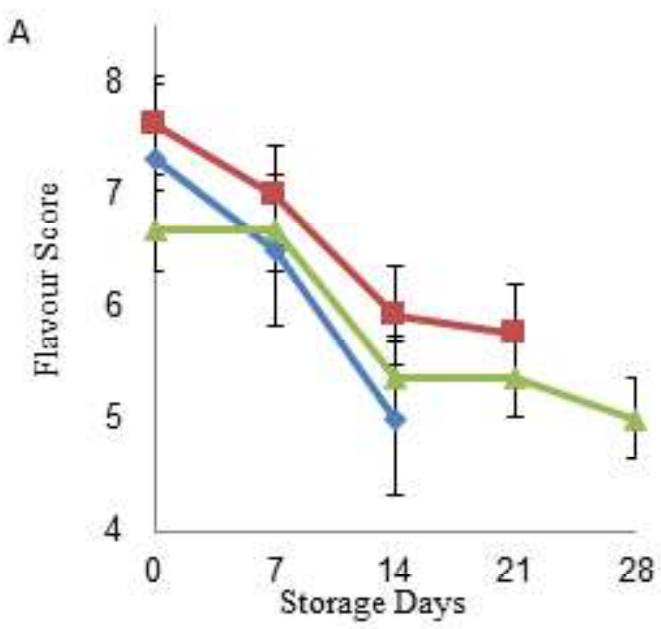

(b) Pinni packed in polystyrene trays

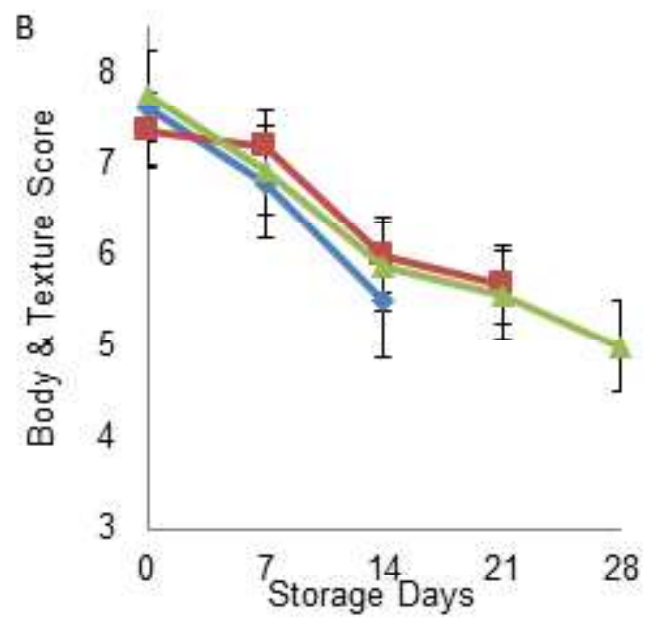

(b) Pinni packed in polystyrene trays

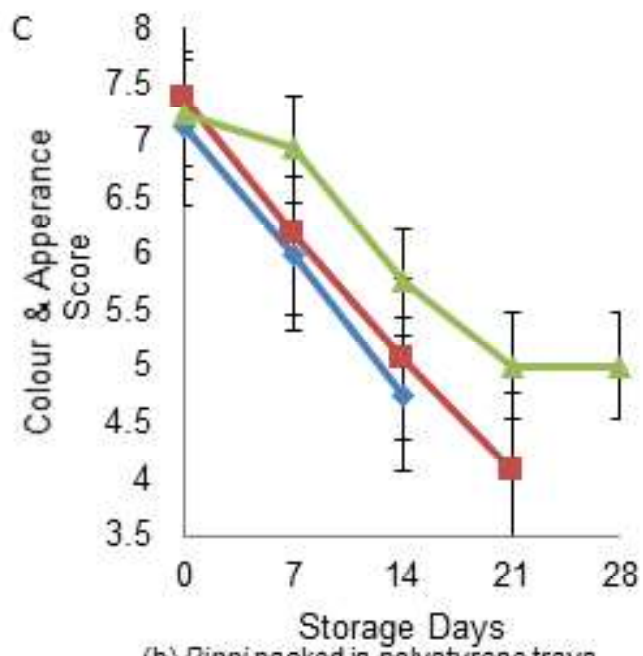

(b) Pinni packed in polystyrene trays 

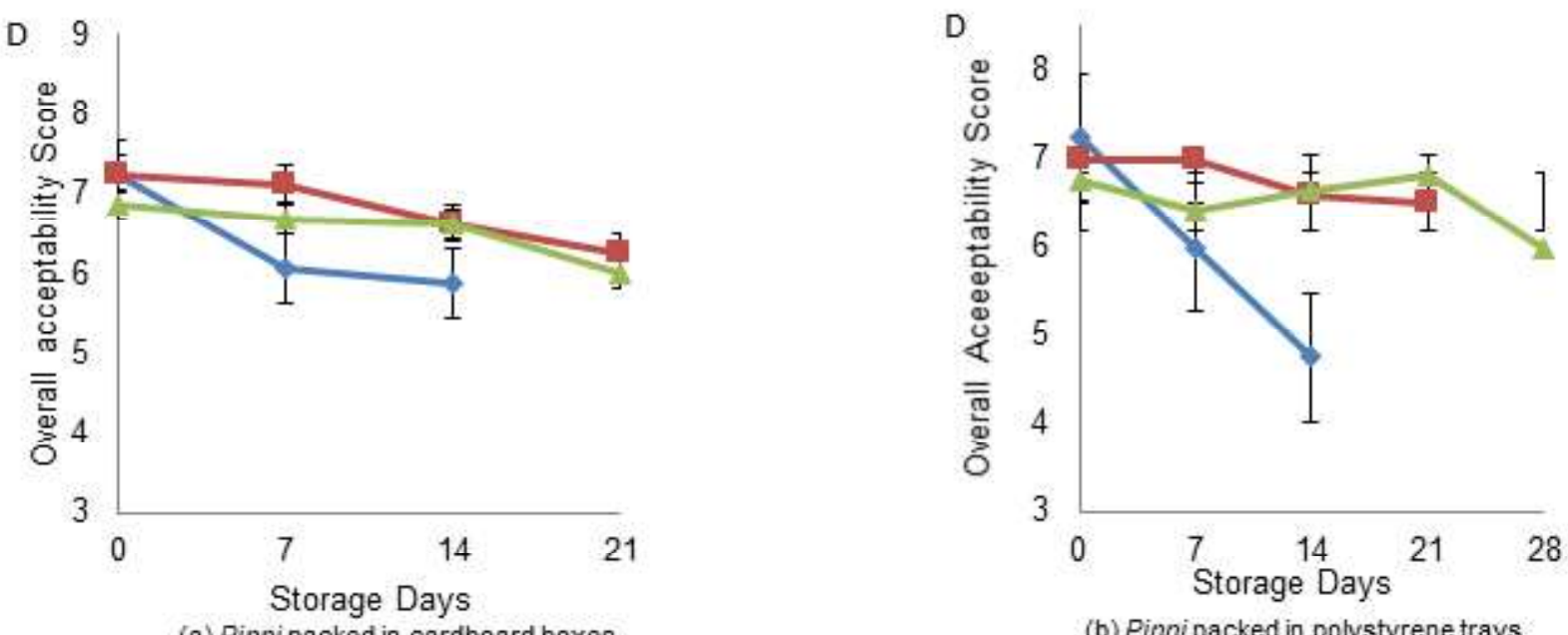

(a) Pinni packed in cardboard boxes

(b) Pinni packed in polystyrene trays

Fig. 1 Effect of natural preservatives and packaging techniques on sensory attributes of pinni during storage at $30 \pm 1$ ÚC (A: Flavour, B: Body \& Texture Score, C: Colour \& Appearance Score and D: Overall acceptability) ( Control sample, Cardamom added and Rosemary added pinni sample

$\triangle$
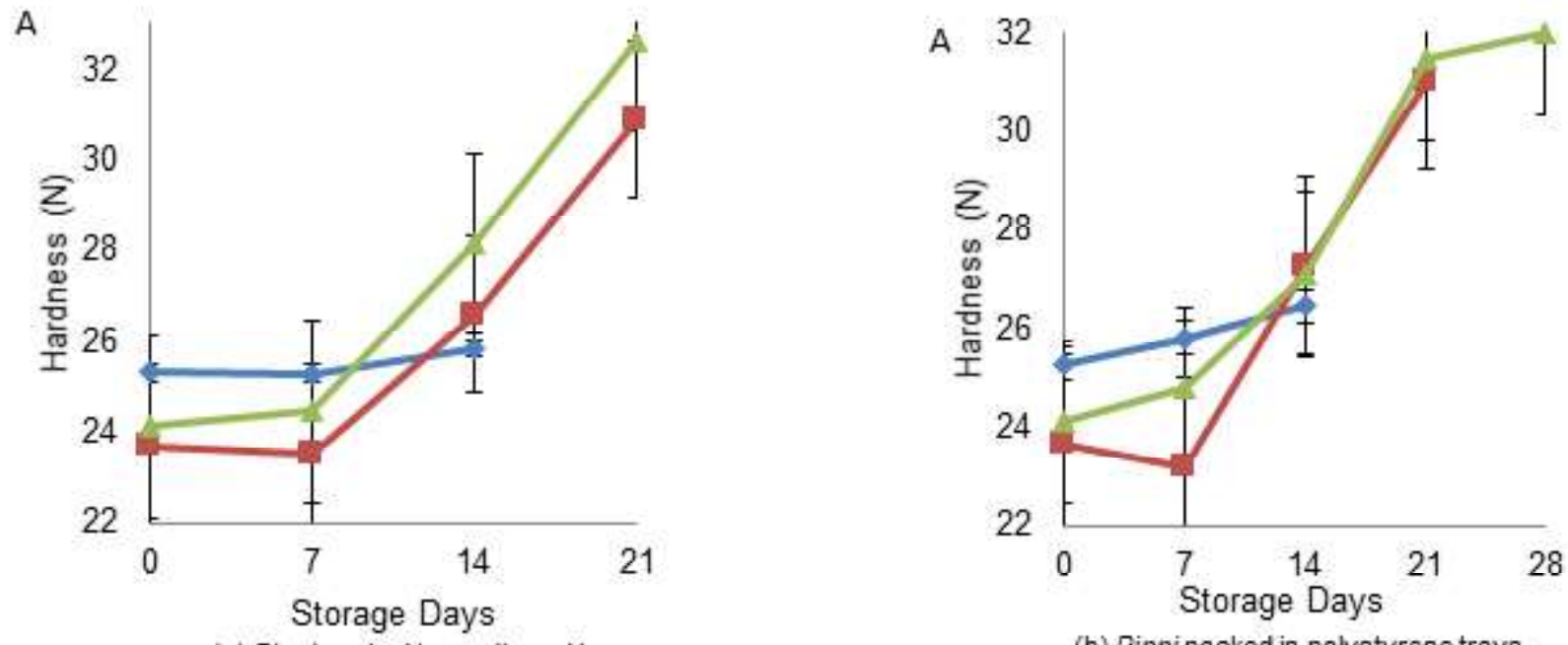

(a) Pinni packed in cardboard boxes

(b) Pinni packed in polystyrene trays

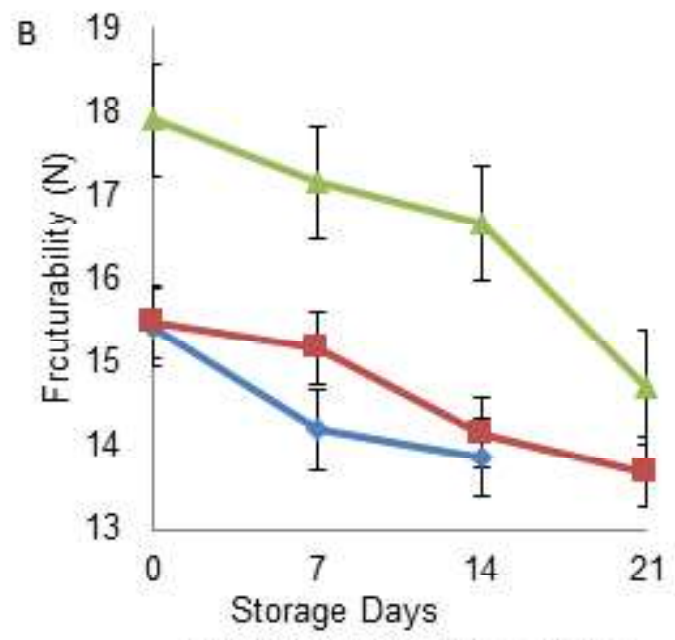

(a) Pinni packed in cardboard boxes

B

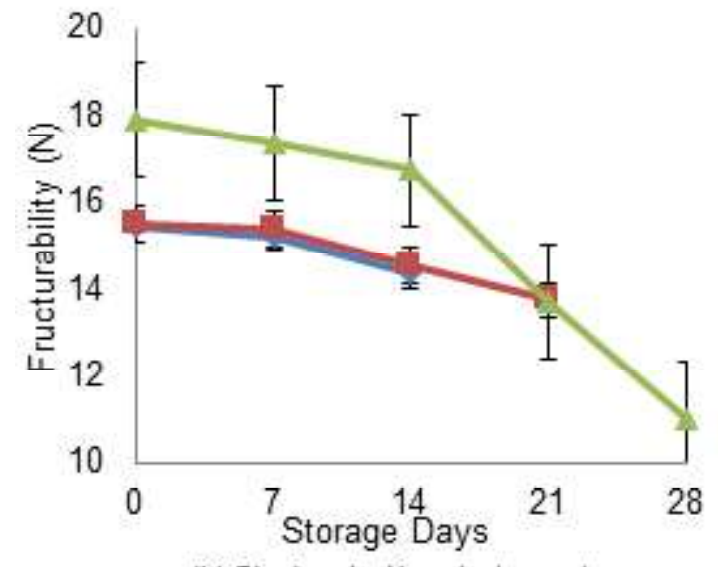

(b) Pinni packed in polystyrene trays 

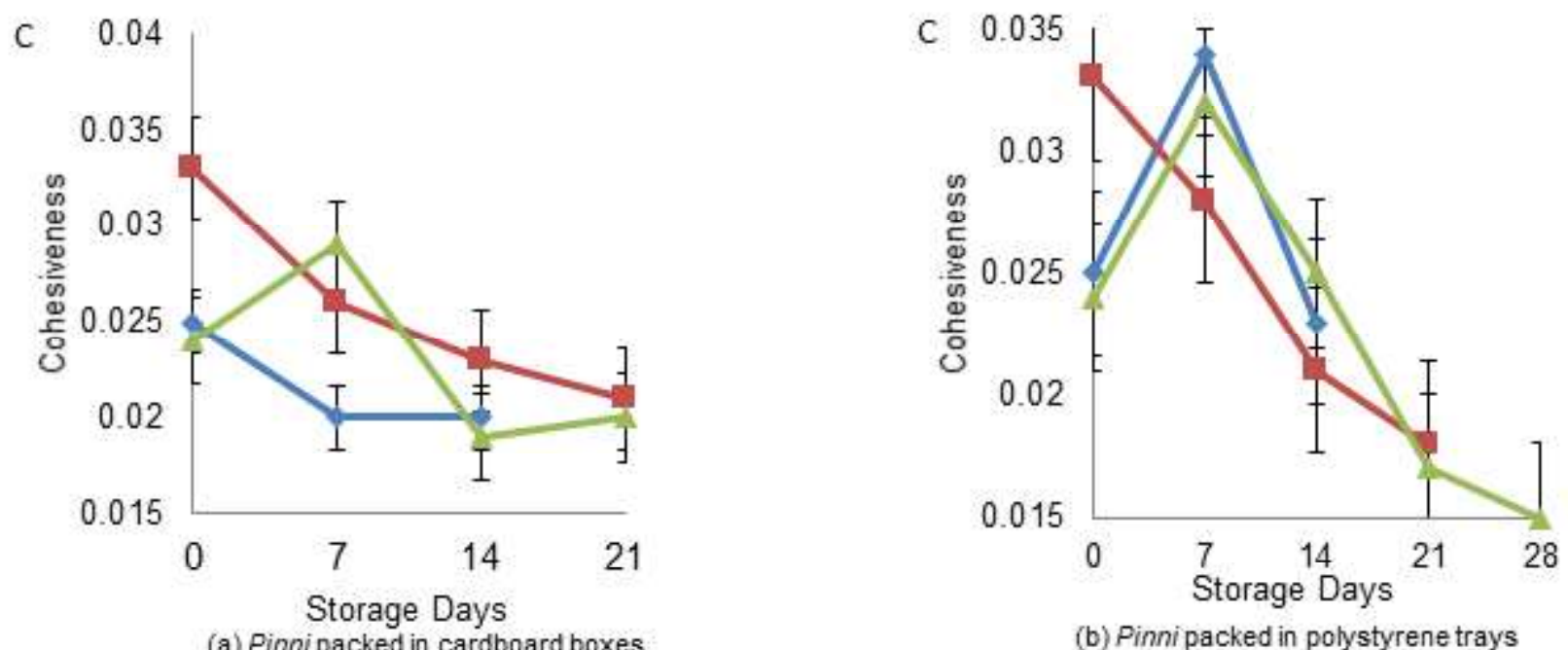

(a) Pinni packed in cardboard boxes

(b) Pinni packed in polystyrene trays
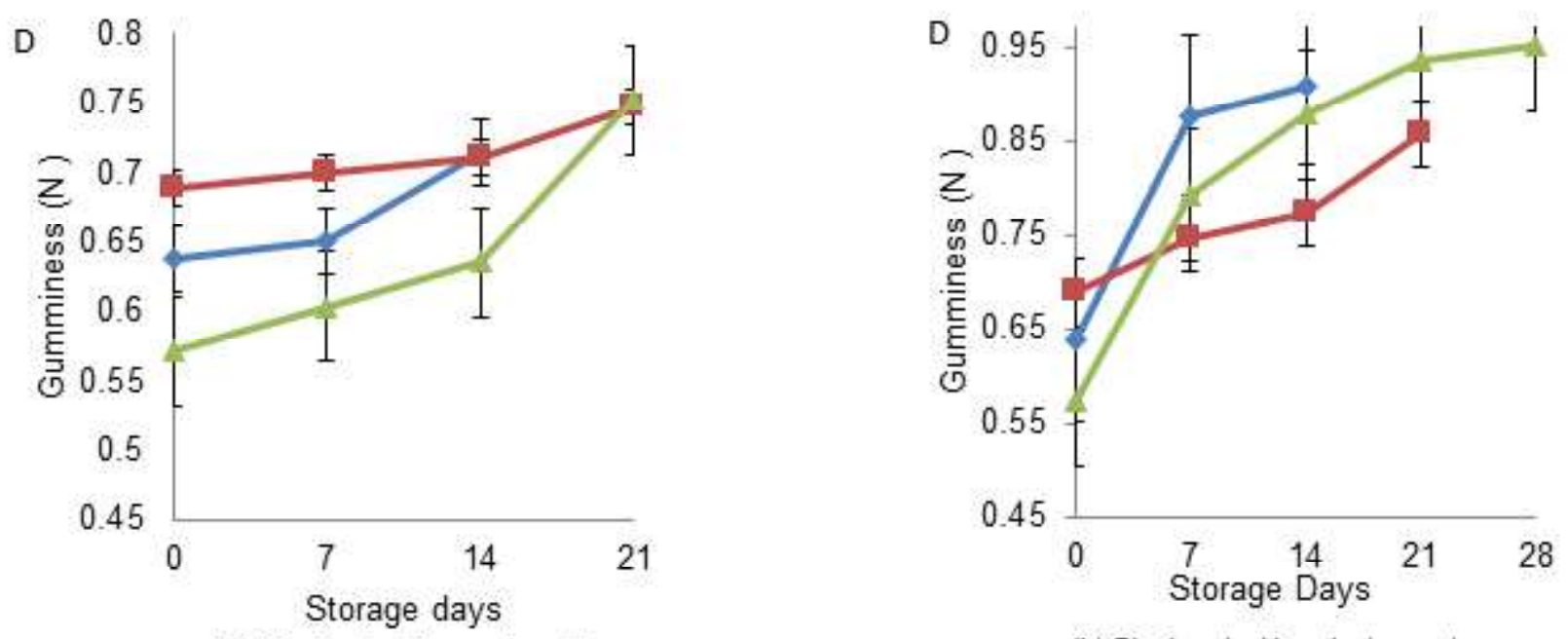

(a) Pinni packed in cardboard boxes

(b) Pinni packed in polystyrene trays
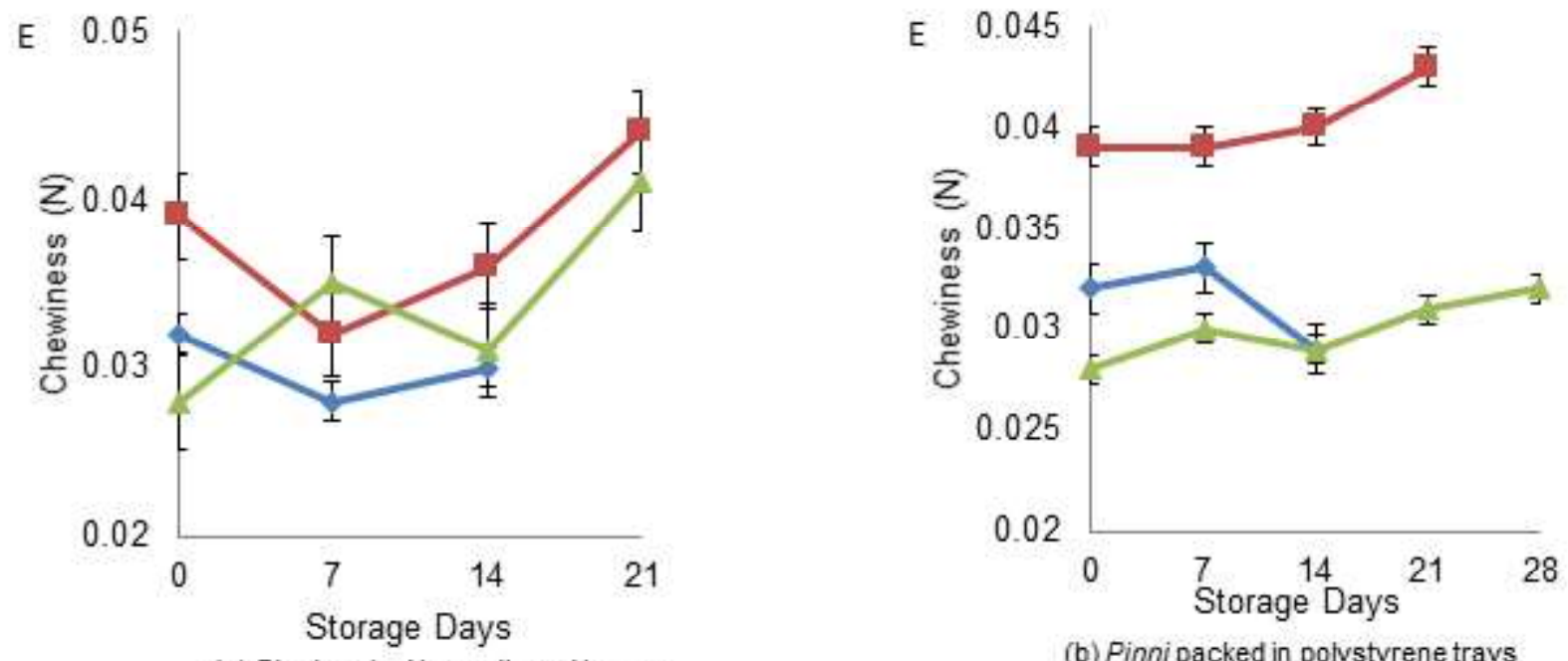

(a) Pinni packed in cardboard boxes

(b) Pinni packed in polystyrene trays

Fig. 2 Effect of natural preservatives and packaging techniques on textural parameters of pinni during storage at $30 \pm 1{ }^{\circ} \mathrm{C}(\mathrm{A}$ : Hardness; B: Frcuturability; C: Cohesiveness D: Gumminess; E: Chewiness) ( $\diamond$ Control sample, $\square$ Cardamom added and $\Delta$ Rosemary added pinni sample) 


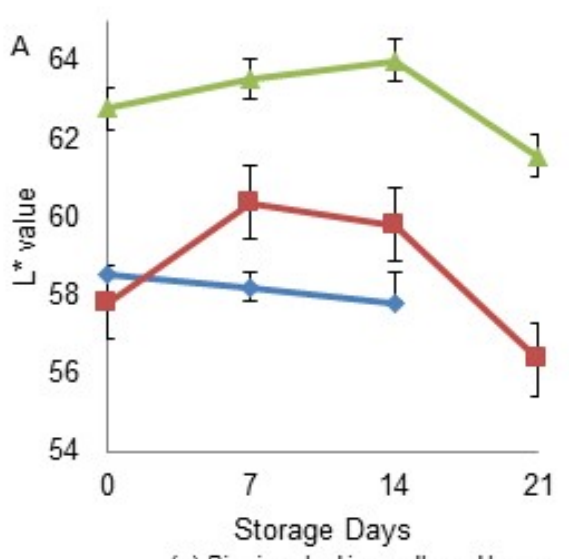

(a) Pinni packed in cardboard boxes

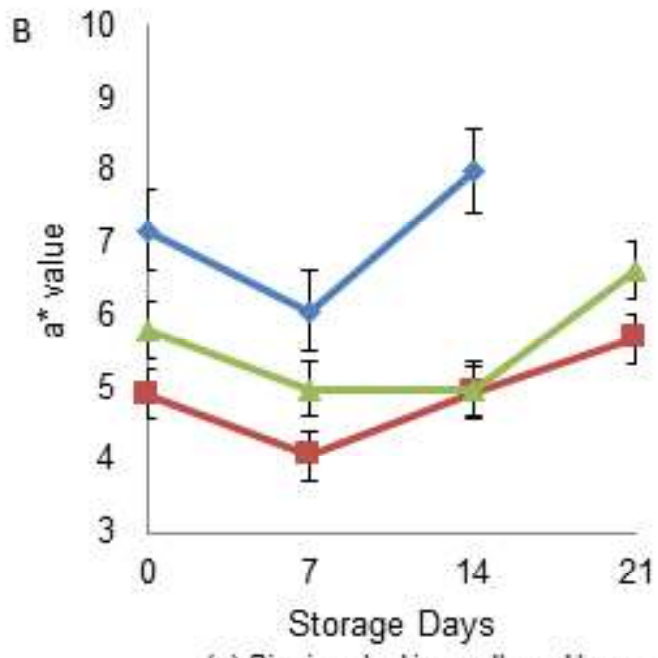

(a) Pinni packed in cardboard boxes

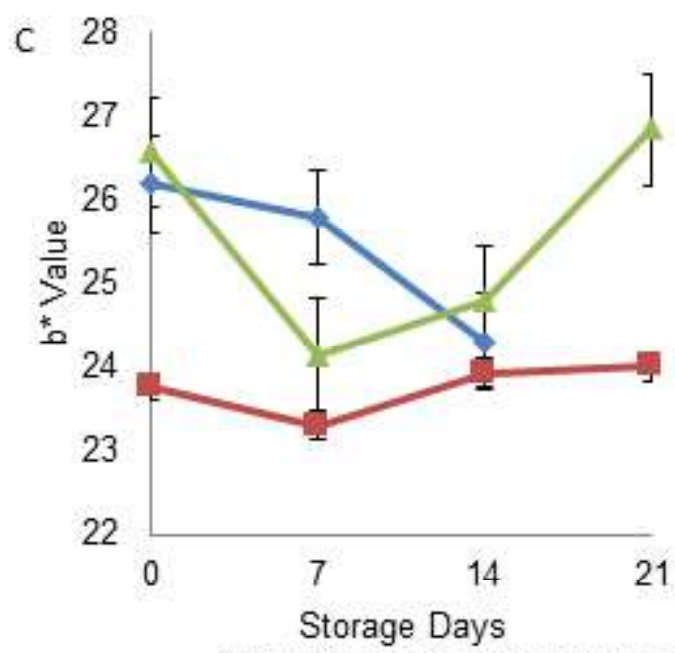

(a) Pinni packed in cardboard boxes

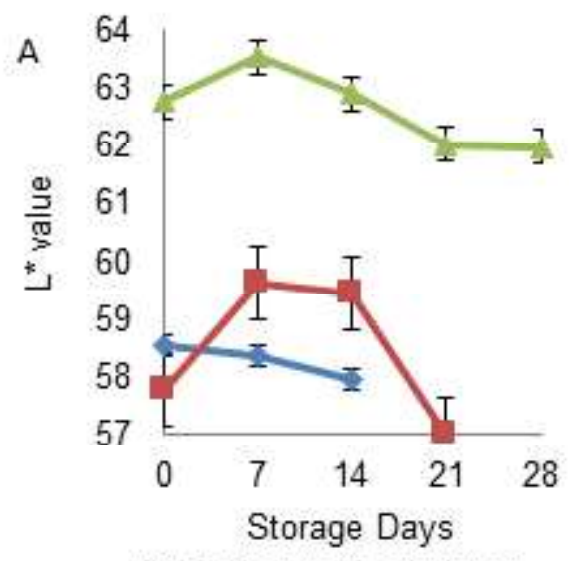

(b) Pinni packed in polystyrene

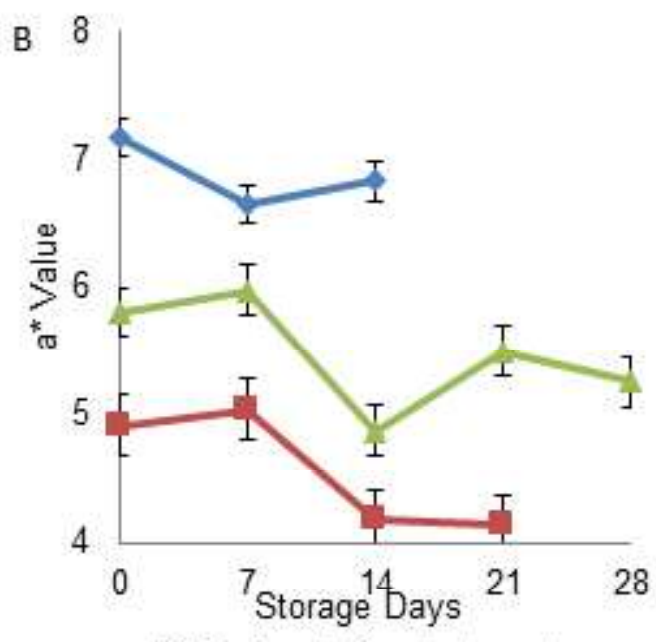

(b) Pinni packed in polystyrene trays

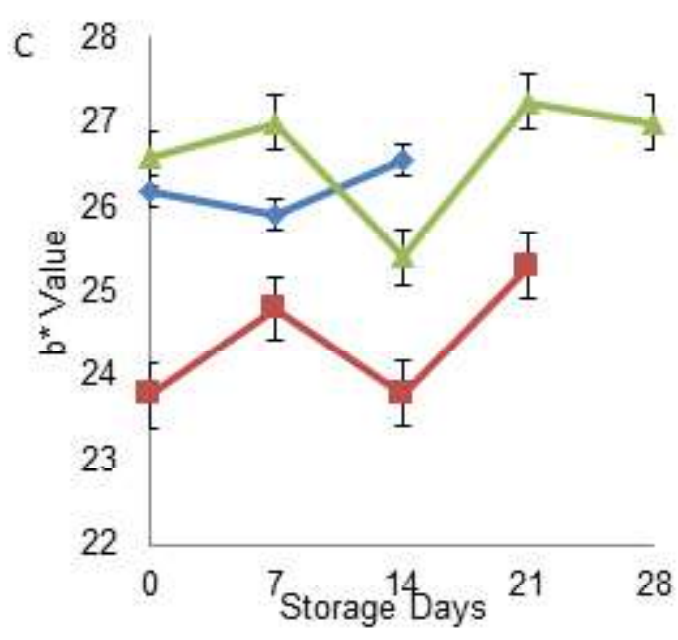

(b) Pinni packed in polystyrene trays

Fig. 3 Effect of natural preservatives and packaging techniques on colour attributes of pinni during storage at $30 \pm 1{ }^{\circ} \mathrm{C}\left(\mathrm{A}\right.$ : $\mathrm{L}^{*}$ value; $\mathrm{B}: \mathrm{a}^{*}$ value; $\mathrm{C}: \mathrm{b}^{*}$ value) ( $\diamond$ Control sample, $\square$ Cardamom added and $\triangle$ Rosemary added pinni sample) 


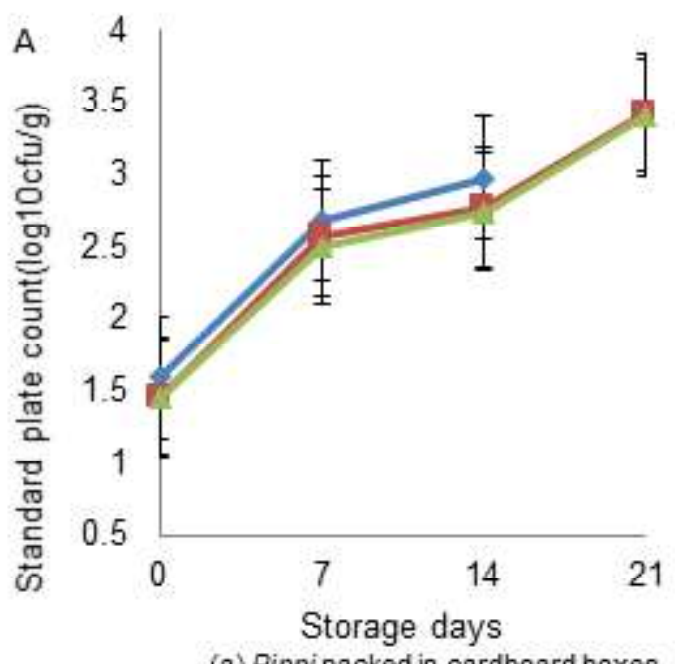

(a) Pinni packed in cardboard boxes

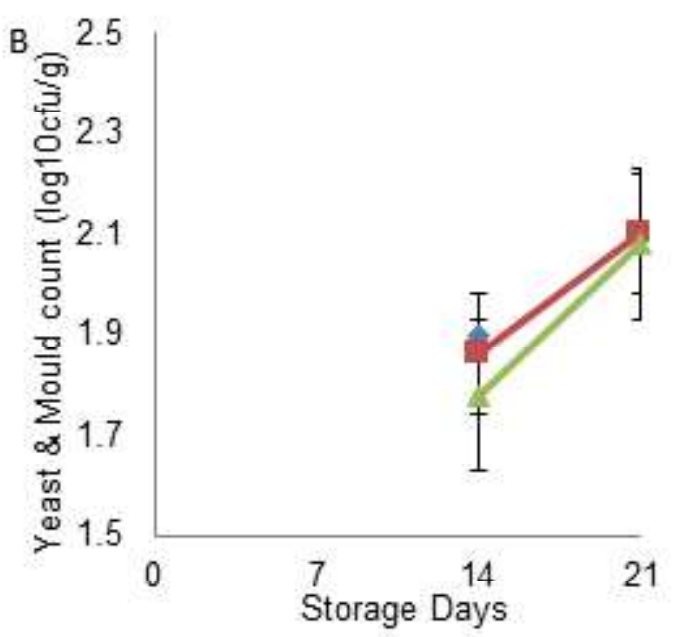

(a) Pinni packed in cardboard boxes

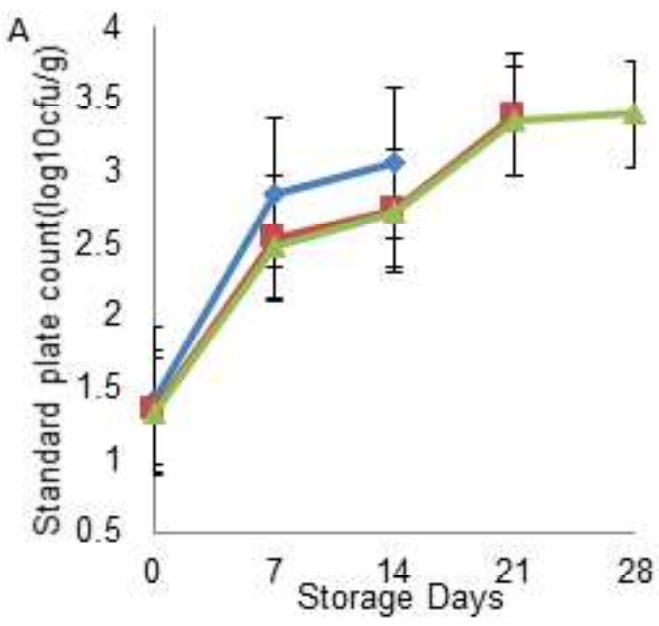

(b) Pinni packed in polystyrene trays

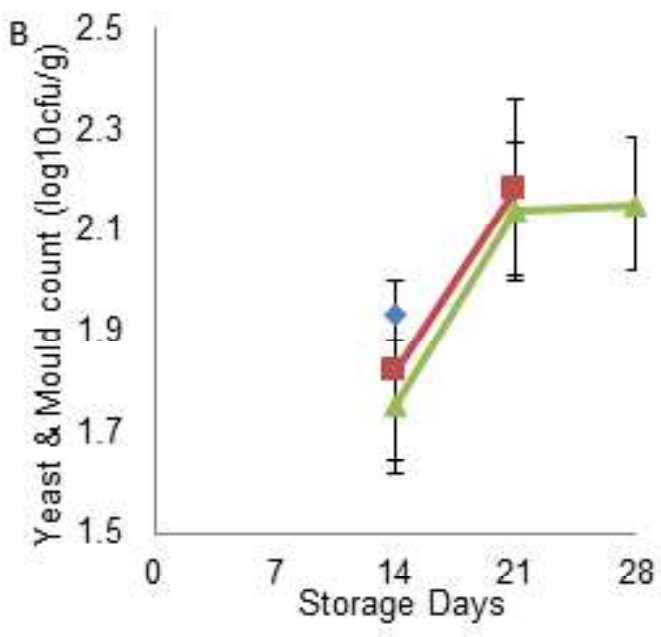

(b) Pinni packed in polystyrene trays

Fig. 4 Effect of natural preservatives and packaging techniques on microbiological parameters of pinni during storage at $30 \pm 1{ }^{\circ} \mathrm{C}$ (A: Total standard plate count; B: Total yeast mould count) ( $\diamond$ Control sample, $\square$ Cardamom added and $\triangle$ Rosemary added pinni sample)

et al. (1992a). Khamrui and Solanki (2010) reported increase in chewiness of sandesh during storage. As because cardamom and rosemary extract added in ppm levels their addition had no effect on any of the textural attributes of pinni in both the packaging materials.

\section{Changes in colour attributes of pinni during storage}

Colour of any food product assumes a great significance from consumers' acceptance point of view. Changes in $\mathrm{L}^{*}$ value of pinni packed in cardboard boxes and PS trays store at $30 \pm 1^{\circ} \mathrm{C}$ is presented in Fig. 3. The average $\mathrm{L}^{*}$ value of control and cardamom added pinni samples decreased significantly $(\mathrm{p}<0.05)$ in cardboard boxes after 21 days and in rosemary added pinni samples PS tray packed samples after 28 days. Gothwal and Shukla (1995) reported the effect of refined wheat flour and sugar on the browning of khoa-based sweets such as burfi and kalakand. The average a* value of rosemary added pinni samples increased significantly $(\mathrm{p}<0.05)$ in cardboard boxes after 21 days and significantly $(\mathrm{p}<0.05)$ decreased after 28 days when pinni packed in PS trays Prasad et al. (2017b) also observed increased redness value of control and herbal burfi during storage at $37 \pm 1 \mathrm{U} C$ and $4 \pm 1^{\circ} \mathrm{C}$ when packed in cardboard and high-density polyethylene (HDPE) boxes. Samples packaged in PS trays had significant $(p<0.05)$ increase in $\mathrm{b}^{*}$ value after 28 days of storage in case of rosemary added pinni samples and 21 days in case of cardamom added pinni samples. Londhe et al. (2012) reported increase in $\mathrm{b}^{*}$ value of peda when packaged in cardboard boxes and found decrease in the $b^{*}$ value of samples packed in vacuum packed 5-layer nylon from initial value of 34.28 to 33.48 after 40 days of storage. 


\section{Microbiological changes in pinni during storage}

The microbiological changes in pinni packaged under different packaging conditions during storage are given in Fig. 4. During storage all the samples showed an increasing trend in standard plate count in both the packaging materials. Total plate counts were significantly higher in control product than cardamom and rosemary added pinni samples indicating preservation effect of cardamom and rosemary extract. Increase in SPC of burfi and brown peda during storage had been reported by earlier workers (Reddy, 1992; Londhe 2006). However, Kumar and Srinivasan, (2010) did not observe any microbial growth in peda packed under MAP and with oxygen scavengers. Yeasts and moulds in fresh pinni were not detected during initial period of storage however it significantly $(\mathrm{p}<0.05)$ increased controlled pinni samples after 14 days of stored at $30 \pm 1$ ÚC in both packaging materials (Fig 4). Lower extent of increase in yeast and mould count in PS trays was probably due to higher barrier properties of polystyrene tray as compared to cardboard boxes. Results are in agreement with the earlier finding of Palit and Pal (2005) and Rajarajan and Lango, (2006). Germicidal effect of cardamom has also been reported by Gaikwad and Hembade (2012) in Ujani Basundi.

\section{Conclusions}

The present study attempted for enhancement of shelf life of pinni by adding two natural preservatives viz., cardamom powder and rosemary extrcat and by using different packaging interventions. It was observed that control samples of pinni were organoleptically unacceptable after 14 days in both the packaging materials when stored at $30^{\circ} \mathrm{C}$. However, cardamom powder added pinni samples have a shelf life 21 days when packed in cardboard boxes as well as when packed PS trays. Total plate counts and yeast and mould counts were significantly higher in control sample than cardamom and rosemary extract added pinni samples indicating preservation effect of cardamom and rosemary extract. Pinni could be best preserved up to 28 days at room temperature ( $30 \pm 1$ ÚC) without much quality loss when packed in polystyrene trays and added with rosemary extract.

\section{Acknowledgments}

Thankful acknowledgement to the Director, ICAR-National Dairy Research Institute for providing economic assistance in the form of institutional fellowship constituted by Indian Council of Agricultural Research, New Delhi and other infrastructural amenities for conducting the presented research work.

\section{References}

Adhikari AK, Mathur ON, Patil GR (1992a) Micro-and macro-structure of cow, buffalo and mixed milk rasogolla: a comparative scanning electron and light microscope study. Le Lait 72: 475-489

Bhatele ID (1983) Studies on the production, packaging and preservation of burfi. Ph.D Thesis Kurukshetra University, Kurukshetra
Bourne MC (2002) Texture Profile Analysis. Food Texture and Viscosity, Academic Press London, pp 182-188

Chawla R, Patil GR, Singh AK (2015a) Effect of temperature on sensory and textural attributes of functional doda burfi (Indian milk cake). J Food Sci Technol 52: 586-591

Chawla R, Singh AK, Patil GR (2015b) Shelf life enhancement of functional doda burfi (indian milk cake) with bio preservatives application. Int J Res Sci Technol 5: 26-40

De S (2004) Outlines of Dairy Technology. $2^{\text {nd }}$ ed. Oxford University Press, New Delhi

Gaikwad SM, Hembade AS (2012) Effect of storage temperature on shelf life of standardized buffalo milk basundi. Int J Livest Prod 2: 205211

Ghayal G, Jha A, Kumar A, Gautam AK, Rasane P (2015) Effect of modified atmospheric packaging on chemical and microbial changes in dietetic rabri during storage. J Food Sci Technol 52: 1825-1829

Gothwal PP, Bhavadasan MK (1992) The role of proteins in browning in milk. Indian J Dairy Sci 45: 419-423

Gothwal PP, Shukla IC (1995) Effect of refined wheat flour (maida) and sugar on the browning of milk, khoa and khoa-based sweets. J Food Sci Technol $32: 301-304$

Goyal GK, Rajorhia GS (1991) Role of modern packaging in marketing of Indigenous dairy products. Indian Food Indu 10: 32-34

Gupta SK, Patil GR, Patel AA, Garg FC, Rajorhia GS (1990) Instron texture profile parameters of khoa as influenced by composition. J Food Sci Technol 27: 209-213

IS: SP 18 (Part XI) (1981) Handbook of food analysis. Part XI., Dairy Products. Bureau of Indian Standards. Manak Bhavan, New Delhi

Jha A, Kumar A, Jain P, Gautam AK, Rasane P (2014a) Effect of modified atmosphere packaging on the shelf life of lal peda. J Food Sci Technol 52: 1068-1074

Jha A, Kumar A, Jain P, Om H, Singh R, Bunkar DS (2014b) Physicochemical and sensory changes during the storage of lal peda. J Food Sci Technol 51: 1173-1178

Jessica EDLT, Gassara F, Kouassi AP, Brar SK, Belkacemi K (2015) Spice use in food: Properties and benefits. Crit Rev Food Sci Nutr 57: 1078-1088

Khamrui K, Solanki DC (2010) The relationship of textural characteristics with composition of sandesh produced from various market milk classes. Int J Dairy Technol 63: 451-456

Kotsianis IS, Giannou V, Tzia C (2002) Production and packaging of bakery products using MAP technology. Trends Food Sci Technol 13: $319-324$

Kumar G, Srinivasan MR (2010) Effect of antioxidants on shelf life of khoa under refrigerated conditions. Egyptian J Dairy Sci 38: 211218

Loliger J (1983) Natural antioxidants. In J.C. Allen, and R. J. Hamilton (Eds.). Rancidity in Foods, pp. 89-107

Londhe GK (2006) Development of a process for manufacture and shelf life extension of brown peda, PhD Thesis, Dairy Technology Division, National Dairy Research Institute, Deemed University, Karnal, India

Londhe G, Pal D, Raju PN (2012) Effect of packaging techniques on shelf life of brown peda, a milk-based confection. LWT-Food Sci Tech 47: $117-125$

Menefee SG, Overman OR (1940) A semimicro-kjeldahl method for the determination of total nitrogen in milk. J Dairy Sci 23: 1177-1185

Mishra AK, Kuila RK (1988) Microboilogical quality of burfi and sandesh. Asian J Dairy Res 7: 51-55

Nalwade V, Puri R, Lodh J, Khamrui K (2014) Instrumental colour profile of dieteic sandesh as function of ingredients using response surface methodology. Indian J Dairy Sci 67: 467-475 
Palit C, Pal D (2005) Studies on mechanized production and shelf life extension of burfi. Indian J Dairy Sci 58: 12-16

Pandey A, Singh G (2011) Development and storage study of reduced sugar soy containing compound chocolate. J Food Sci Technol 48: $76-82$

Peiretti P, Gai F, Ortoffi M, Aigotti R, Medana C (2012) Effects of rosemary oil (Rosmarinus officinalis) on the shelf-life of minced rainbow trout (Oncorhynchus mykiss) during refrigerated storage. Foods 1: 28-39

Prabha S (2006) Development of Technology for the Manufacture of Dietetic Burfi, Ph.D Thesis, ICAR- National Dairy Research Institute, Deemed University, Karnal, India

Prasad W, Khamrui K, Mandal S, Badola R (2017a) Anti-oxidative, physicochemical and sensory attributes of burfi affected by incorporation of different herbs and its comparison with synthetic anti-oxidant (BHA). J Food Sci Tech 54: 3802-3809.

Prasad W, Khamrui K, Sheshgiri S (2017b) Effect of packaging materials and essential oils on the storage stability of burfi, a dairy dessert. J Pack Technol Res 1: 181-192

Rahila MP, Surendra Nath B, Laxmana Naik N, Pushpadass HA, Manjunatha M, Franklin MEE (2017) Rosemary (Rosmarinus officinalis Linn.) extract. A source of natural antioxidants for imparting autoxidative and thermal stability to ghee. J Food Proc Pres 24: 1445-1451

Rajarajan N, Kumar, AE Lango (2006) Incidence of yeast and mould in khoa. J Dairy Food Home Sci 25: 152-154

Reddy CR, Rajorhia GS (1992) Present status of peda and burfi technologya review. Indian J Dairy Sci 45: 220-225

Saxena AK, Kulkarni SG, Berry SK, Sehgal RC, Beerh OP (1996) Preparation, packaging and storage of pinni. an Indian traditional sweet. J Food Sci Technol 33: 503-505

Sharma HK, Singhal RS, Kulkarni PR (2003) Effect of modified atmosphere packaging on the keeping quality of malai peda. J Food Sci Technol 40: $543-545$

Suresh I, Jha YK (1994) Sensory, biochemical and microbiological qualities of kalakand. J Food Sci Technol 31: 330-332

Talwar G, Brar SK (2015) Study of physiochemical, sensory and color properties of pinni variants. Indian J Sci Technol 8: 629

Vijaylakhshmi V, Smith SC, Gamlath S (2014) Consumer acceptability and antioxidant potential of probiotic-yogurt with spices. LWT-Food Sci Technol 55: 255-262 